\title{
DETECTION MECHANISMS IN SUPERCONDUCTING POINT CONTACTS AT FREQUENCIES OF 44 TIMES THE ENERGY GAP
}

\author{
D. G. McDonAld, F. R. PETERSEN, J. D. CUPP, \\ B. L. DANIELSON and E. G. JOHNSON \\ Institute for Basic Standards, National Bureau of Standards \\ Boulder, Colorado, USA
}

\begin{abstract}
Résumé. - Nous avons réalisé à l'aide de contacts supraconducteurs des expériences de mélange avec des lasers à $\mathrm{CO}_{2}$ dans un domaine de longueurs d'ondes situé entre 9 et $11 \mu$. Les fréquences intermédiaires varient entre $19 \mathrm{MHz}$ et $106 \mathrm{GHz}$. Le mécanisme de mélange dépend sans aucun doute de l'état supraconducteur car l'amplitude du signal de battement décroît de plus de $60 \mathrm{~dB}$ lorsque la température du bain s'élève au-dessus de la température de transition. On peut envisager trois mécanismes différents pour rendre compte de la réponse observée : 1) un effet Josephson classique, 2) un effet Josephson modulé thermiquement et 3) un effet tunnel à une seule particule. La preuve usuelle d'un effet Josephson est la présence de marches dans la caractéristique $I-V$. Les marches, dont la première devrait être située à $67 \mathrm{mV}$, n'ont pas été observées, cependant nous ne considérons pas cette expérience comme un test définitif du mécanisme de mélange entre deux sources externes à de si hautes fréquences. En réalité, la théorie de Werthamer sur les jonctions tunnel prédit une réponse aussi importante pour ces fréquences que pour deux sources rayonnant en bande $\mathrm{X}$ par exemple. On doit noter que la théorie suppose que la jonction est maintenue à une température constante et que cela dépend de la densité de courant dans le contact dont on ne sait rien actuellement. Ces expériences insistent sur un paramètre qui est usuellement négligé lorsqu'on effectue des mélanges à l'aide d'un oscillateur local externe : lorsque le contact ou la région où l'effet tunnel se produit sont suffisamment petits, ils subissent une modulation thermique à la fréquence intermédiaire même dans le domaine des microondes. Cet effet devient d'autant plus vraisemblable que la fréquence est plus élevée, en particulier lorsqu'elle correspond à un rayonnement infrarouge. Un modèle théorique permettant de calculer la sensibilité ultime de ces dispositifs exige de prendre en compte ces effets thermiques. On doit s'attendre à des signaux intermédiaires de grande amplitude même aux fréquences optiques, si les effets thermiques n'induisent pas une limitation.
\end{abstract}

Abstract. - We have performed mixing experiments with $\mathrm{CO}_{2}$ lasers in the 9 to $11 \mu \mathrm{m}$ wavelength band using superconducting point contacts. The experiments involve difference frequencies ranging from $19 \mathrm{MHz}$ to $106 \mathrm{GHz}$. The mixing mechanism definitely appears to require the superconducting state since the beat signal amplitude decreases by as much as $60 \mathrm{~dB}$ as the bath temperature is raised through the superconducting transition temperature. At least three conceptually distinguishable mechanisms may be involved in the observed response. These include : (1) a conventional Josephson response, (2) a thermally modulated Josephson response, and (3) a single particle tunneling response. The usual signature of a Josephson interaction is one or more current steps in the $I-V$ curve. Steps, the first of which should be at $67 \mathrm{mV}$, are not observed in these experiments. However, we do not feel that is a definitive test for the mixing mechanism between two external sources at such high frequencies. In fact, Werthamer's theory of tunnel junctions predicts a large response for these experiments, a response as large as that from two X-band sources, for example. It should be noted, however, that the theory assumes the junction is maintained at a fixed low temperature and whether or not that is the case depends directly on the current density at the contact. Very little is known about the current density at the present time. These experiments emphasize a fact that is usually overlooked in Josephson junction mixing experiments with an external local oscillator. If the contact or tunneling region is sufficiently small, it may be thermally modulated at difference frequencies extending into the microwave range. This effect becomes more likely with increasing applied frequencies, particularly in the infrared. Theoretical modeling for the purpose of calculating ultimate sensitivities of these devices requires a detailed consideration of thermal effects. We fully expect large mixing signals from Josephson junctions even at optical frequencies if thermal effects do not prove to be a limitation. 